\title{
Paideusis
}

\section{Resonance and the Photographing of Medieval Architecture}

\section{Stuart Richmond}

Volume 16, Number 3, 2007

URI: https://id.erudit.org/iderudit/1072490ar

DOI: https://doi.org/10.7202/1072490ar

See table of contents

Publisher(s)

Canadian Philosophy of Education Society

ISSN

0838-4517 (print)

1916-0348 (digital)

Explore this journal

Cite this article

Richmond, S. (2007). Resonance and the Photographing of Medieval Architecture. Paideusis, 16(3), 69-82. https://doi.org/10.7202/1072490ar
Article abstract

In this essay I aim to convey in text and photographs what it might mean to experience medieval architecture with some degree of connectivity or what Wittgenstein calls, poetically, "resonance." I provide examples of personal experiences of medieval architecture, and argue for the importance of historical knowledge, sensuous acquaintance, and a sympathetic imagination in gaining a resonant affiliation. Photography, I want to show, is a way of engaging aesthetically with medieval architecture that can, on occasion, lead to the making of images that serve as authentic reminders of the original experience.
This document is protected by copyright law. Use of the services of Erudit (including reproduction) is subject to its terms and conditions, which can be viewed online.

https://apropos.erudit.org/en/users/policy-on-use/ 
Paideusis, Volume 16 (2007), No. 3, pp. 69-82

\title{
Resonance and the Photographing of Medieval Architecture
}

\author{
STUART RICHMOND \\ Simon Fraser University, Canada
}

In this essay I aim to convey in text and photographs what it might mean to experience medieval architecture with some degree of connectivity or what Wittgenstein calls, poetically, "resonance." I provide examples of personal experiences of medieval architecture, and argue for the importance of historical knowledge, sensuous acquaintance, and a sympathetic imagination in gaining a resonant affiliation. Photography, I want to show, is a way of engaging aesthetically with medieval architecture that can, on occasion, lead to the making of images that serve as authentic reminders of the original experience.

\section{Philosophical Background}

Over the course of the past few years I have spent quite a bit of time photographing medieval architecture. I take the medieval period as approximately 1000-1350. This activity offers an opportunity for me to immerse myself in the past, to see things from a different historical and cultural perspective, and to experience aesthetically the remains of a bygone age. Such times as I have had in contemplating medieval architecture have given me pause for thought regarding the tenor of my own life and have provided me with many intrinsically rewarding experiences. While my interests are mainly experiential, I do sometimes exhibit my photographs. ${ }^{1}$ Given the depth of the subject and the challenge in engaging with centuries-old art, however, whatever I say here can only be a work in progress.

Drawing upon a comment on art from Wittgenstein which I find congenial, I would like to try to convey, using text and photographs, what it might mean for an interested person to experience medieval architecture with some degree of connectivity (I leave a more appropriate wording until a little later), and how photography might aid in this realization. I recognize that when it comes to art we must accept some variation in response due to individual experience and temperament. Also, the issue of the extent to which the viewer-photographer can hope to reach anything like an authentic historical appreciation must be considered. I do not suggest that photography has any necessary conceptual link with the understanding of medieval architecture-only that it may offer one avenue of exploration to persons of suitable interest and ability. I am using a first person narrative to reflect my interest in the engagement with and understanding of medieval architecture.

The salient passage from Wittgenstein, speaking of a "felt expression" in a work of art is: "And you could say too that in so far as people understand it, they 'resonate' in harmony with it, respond to

1 I refer to my recent exhibition, "Photographs of French Romanesque Architecture," Alliance Francaise, Vancouver, Canada, April/May 2006

(C) Copyright 2007. The author, Stuart Richmond, assigns to Paideusis the right of first publication and educational and non-profit institutions a non-exclusive license to use this document for personal use and in courses of instruction provided that the article is used in full and this copyright statement is reproduced. Any other usage is probibited without the express permission of the author. 
it" (1980, p. 58e). For an artist, the conceptual elusiveness of the phrasing is more than made up for by its poetic truth, and Wittgenstein, as is well known, drew a parallel between philosophy and poetry. ${ }^{2}$ It is impossible to know precisely what Wittgenstein meant by this passage. Certainly it is easier to intuit the meaning than explain it analytically, which was probably his point. "Resonate," however, according to my old Chamber's dictionary is described as "to resound; to vibrate sympathetically." "Resonance" equally, is "sympathetic vibration." I like this phrasing as it implies to me, minimally, two bodies in tune with one another, or the one answering the call of another. Perhaps a compassionate affinity is not too far-fetched. Wittgenstein speaks of a harmony of person and art work which implies a coming together or connecting.

So for Wittgenstein, understanding seems to be synonymous with resonance. But if so, resonance seems richer than a grasp of the social and historical attributes of a piece of medieval architecture. Resonance also connotes a sympathetic answering response that is in tune with, or in harmony with, the being and meaning of the other. It implies to me more of an emphasis on sensuous acquaintance than knowledge, something more existential, poetic and ineffable. While, without doubt, historical and artistic ideas inform perception, in practice, in an aesthetic situation, they would seem to be insufficient for achieving a resonant relationship, as I shall argue later.

Resonance also suggests to me a capacity imaginatively to enter into and value (appreciate) the reality of the other, and this is compatible with the case of medieval architecture, which is concerned with human expression in stone. Beneath the metaphorical language, however, resonance connotes the apt perception and interpretation of expressive form. By expression, I mean the qualitative manner in which a theme or idea is formally shaped and presented. Expression is a suitable term, considering the life and ideals associated with medieval architecture. So perhaps I could say there will be resonance between the viewer-photographer and the expressive form, as the one perceives the other, given a suitable historical and aesthetic understanding. However, since Wittgenstein felt it necessary to use a word such as resonance with its poetic overtones to imply understanding, and given the nature of what is to follow, I am reluctant to push too hard in the direction of conceptual analysis.

In summary, in this essay I want to explore what it means in practice to resonate in harmony with a work of medieval architecture, even though this aim might seem peculiar philosophically, eccentric perhaps, and also to convey something of the way in which photography might aid this venture, and at times, lead to new art. Quite obviously, the cultural and temporal distance between life in present day western Canada, where I live, and medieval France is large, but perhaps it is possible, with patience and an informed imagination to get a glimpse of, or feeling for, the atmosphere and spirit of the earlier age.

My approach will be to try to piece together various ideas, discussion, narratives, examples, and photographs with a view to uncovering and sharing some key experiences that give meaning to my photographic explorations. First, I will provide an overview of selected visits I have made to particular abbeys and castles, with photographs, to give some historical background and a sense of place. What I am seeking to show is something of art as lived.

\footnotetext{
${ }^{2}$ Wittgenstein, (1980) notes, "I think I summed up my attitude to philosophy when I said philosophy ought really to be written only as a poetic composition" (p. 24e). There is quite a bit of discussion on the meaning of such statements. In her essay, "But Isn't the Same at Least the Same?" in The Literary Wittgenstein, Marjorie Perloff (2004) argues that the poetic in philosophy for Wittgenstein is more a matter of invention in thinking through the problems of language rather than the use of tropes and poetic language, per se. However, there is no doubt that the phrase "resonate in harmony" noted in the text, as a musical reference transposed to visual art is nicely expressive if not poetic.
} 


\section{Experiencing the Medieval}

\section{Abbaye de Ste-Foy, Conques}

Unusually, the twelfth century Romanesque Benedictine abbey-church of Ste-Foy in the town of Conques-en-Rouergue in the Midi-Pyrenees, lies in a narrow wooded valley not visible from a distance. As will become clear, it was the Cistercians who typically built in remote river valleys, seeking peace and solitude, the Benedictines on the hills and in towns; the Abbey of Ste-Madeleine at Vezelay being one example.

The term "Romanesque" refers to a design in stone that is derived from the rectangular roman basilica, having round arches and vaults, heavy stone columns, thick walls, small windows and simple decoration. Based on this design, Romanesque churches usually had, or have, a central nave with two side aisles, a transept and choir in the shape of a cross, but there were many variations, including a simple rectangle shape with a small apse (Kluckert, 1997). But at Conques, the Abbaye de Ste-Foy is on a branch of the pilgrim trail with its own sacred relics of Ste-Foy, an early Christian martyr, and as such, the church needed to accommodate the needs of pilgrims as well as a community of monks. An abbey is a monastery with a group of monks, usually more than twelve, under the supervision of an abbot, or a convent with nuns and an abbess. What remains at Conques is the abbey-church.

I remember the day in August of 2000 as very bright and hot, as summers in southern France can be. The sun was blinding, unsuitable for photography, so on arrival I walked around the outside of the church, looked for some time at the awe-inspiring relief sculptures on the tympanum above the west door showing the Last Judgment, and went inside.

Here the space was cool, quiet and airy, and because of the day outside was well lit, given the small windows. The church had an incredible physical presence. I liked very much the restrained, if not austere, design and skilled working of the stone, the enclosure of space having what I can only describe as an atmosphere of great peace and tranquility. I was impressed by the fact that this work of art from the twelfth century (1050-1130), still mostly intact, physically existed. I walked slowly around, frequently stood still, and sat at times in contemplation, allowing my senses freely to play over the stones, observing the light fall on the upper arcades and vaulted ceiling, taking in the damp stains and the uneven surfaces, feeling aesthetic pleasure in the beautiful form and qualities of the building, even as I wondered about its genesis and purpose on the pilgrim's trail. During the visit I took about half a dozen photographs, two of which are included here. Perhaps one thing to be said for photography is that it stimulates much careful observation. To the medieval eye such a building in stone, an expensive material and difficult to work with, must have seemed enormous and impressive. Although quite large, in comparison with the later gothic cathedrals it is small, less complicated, and less ornate. ${ }^{3}$

\footnotetext{
${ }^{3}$ A very good local website of interest is http://conques.com/visite16.htm
} 


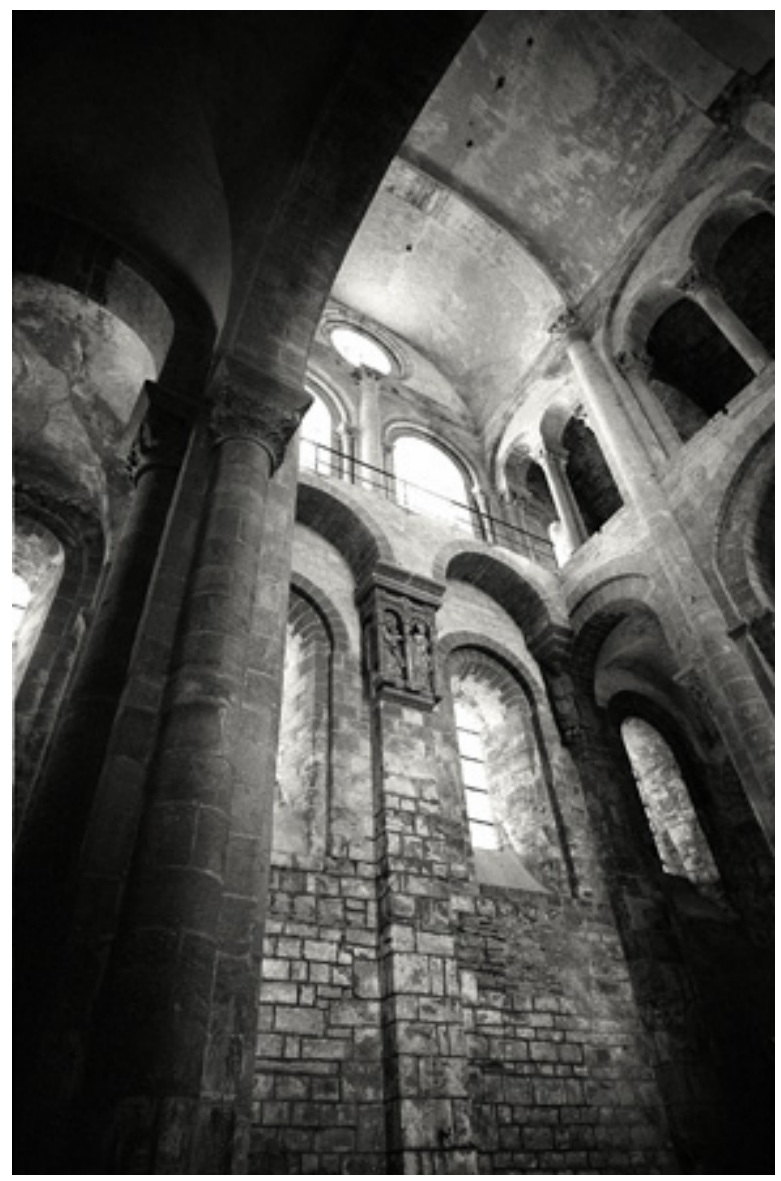

Photo 1: Interior of Conques

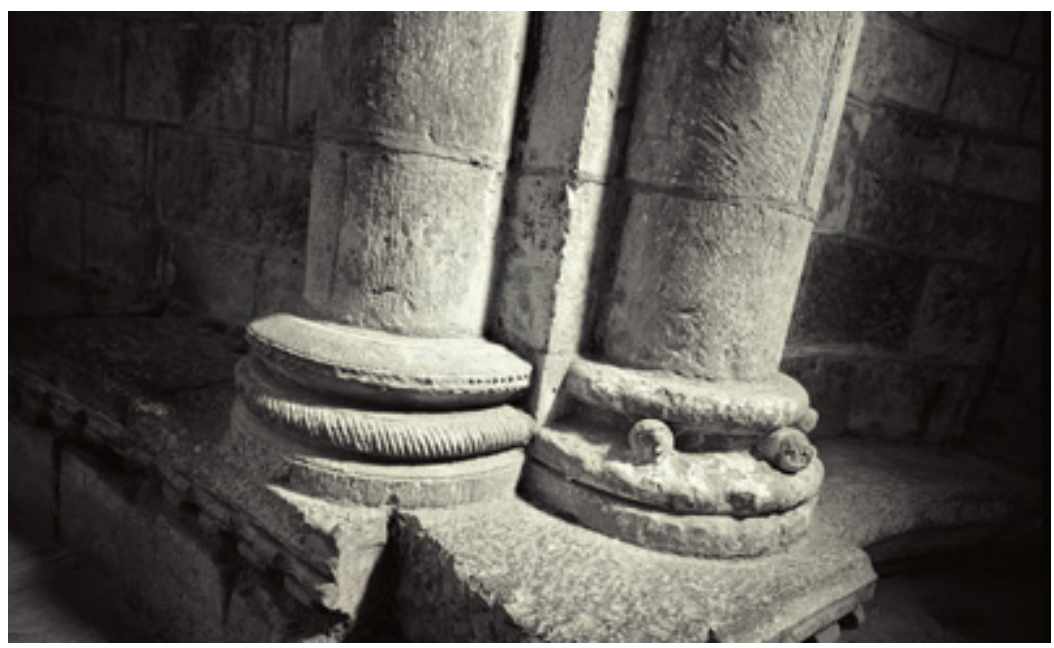

Photo 2: Columns in Nave 


\section{Chateau de Commarque}

Visiting the Dordogne region in March 2004, I saw a poster in a café showing the striking twelfth century Chateau de Commarque and decided to pay a visit. Following the map, I arrived at the designated place but could find nothing but a few houses and forest. Finally I saw a path leading into the trees. There was no other sign or direction. After twenty minutes or so of walking, I reached a ruined end wall of a building, which I took as a good sign. The walk through the stands of oak and beech, with light filtering through leaves, and much birdsong, led me gradually away from the outside world. Then, in the distance, rising dramatically through the tops of trees I saw a high stone medieval keep glinting in the sun that captured my attention for several minutes as the scene, in my imagination, was a pure medieval vision.

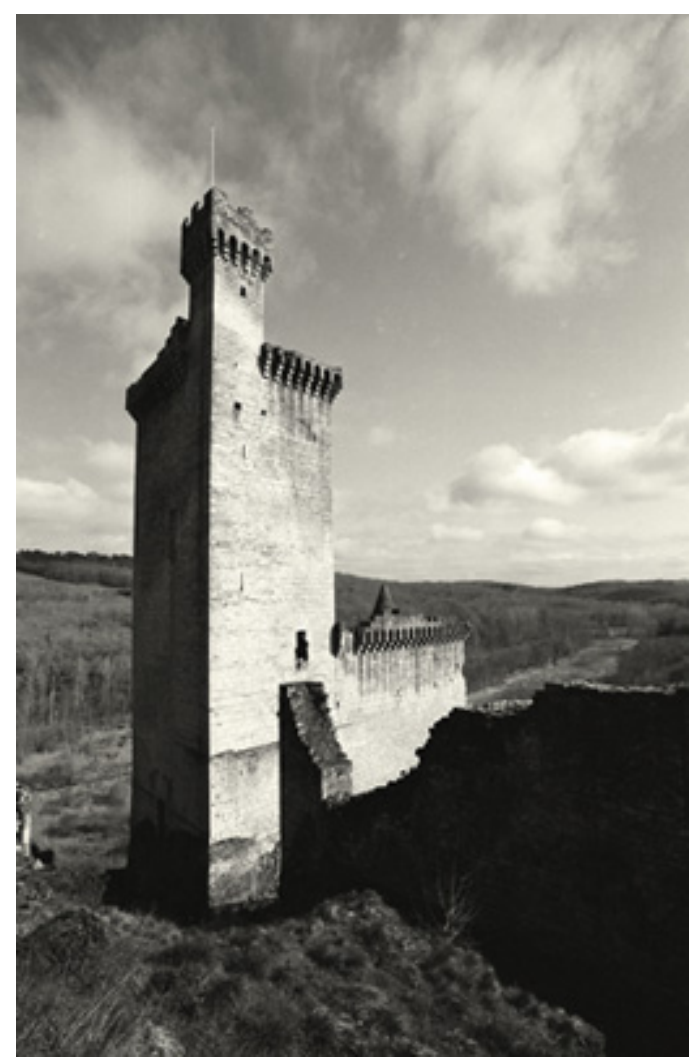

Photo 3: Commarque Keep

I was greeted by two young men working as archeologists on the site. They invited me to go into the keep and gave me a massive iron key for opening the oak door. I went in and immediately felt myself enclosed in a high square tower with archer's slits for windows. I saw worn stone steps leading upwards around the inside walls and went up. Reaching the top I stepped out onto a parapet and then climbed up a second turret and looked out over the rolling forest below. The keep was heightened in the fourteenth century, and machicolations that allowed defenders to drop materials onto an enemy were 
added. ${ }^{4}$ I heard the harsh cry of a circling hawk, otherwise just the wind and silence. In the distance I could see the towers of the ancient Chateau de Laussel. Below me, castle ramparts and ruined structures gave an indication of the original habitation and site. I spent several hours exploring various aspects of the castle, from close and afar, inside and out. I came back next day and did the same thing, stopping to take a few pictures. The castle was reportedly "lost" for many years, overgrown in the forest. Only recently has a family descendent, Hubert de Commarque, begun the work of architectural recovery.

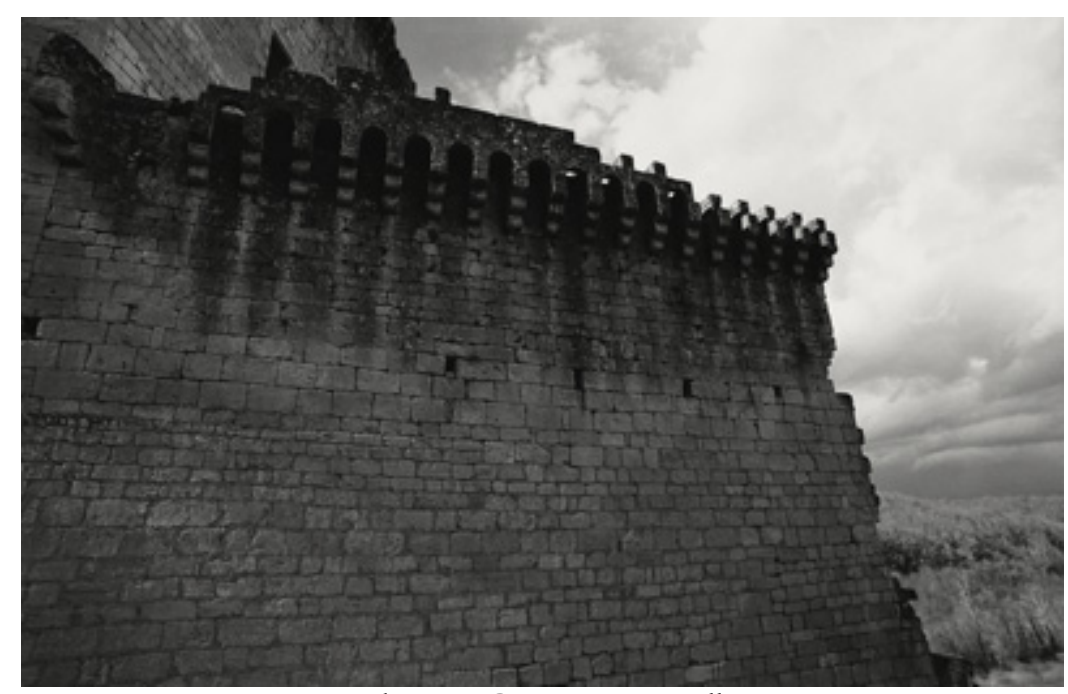

Photo 4: Commarque Wall

\section{Chateau de Vierre}

In northern Burgundy, a chateau I discovered in March 2005-which was named for me by a passing farmer-is the Chateau de Vierre. I visited this chateau three times, without gaining entry into the building, but finding great pleasure wandering through the ancient walled garden with its medieval pond. I took a few pictures one misty morning. For me, the looking, noticing and making small discoveries was very gratifying. I imagine the early tenants, the sounds of voices in French, and the varied animal and bird life, not to mention fish in the nearby trout stream, the lack of engine noise and pollution. The stone walls are cracked in places, overgrown with vines, and the building has arched windows, and a splendid rustic turret. I was able to go inside the similarly-sized and nearby eleventh century Chateau de Chambertin, the castle belonging to the famous vineyard in Burgundy. It has a square tower for defense, which is in good condition, and the house interior is intact with original wooden floors and tapestries inside dark rooms.

\footnotetext{
${ }^{4}$ See, for example, http://www/commarque.com/
} 


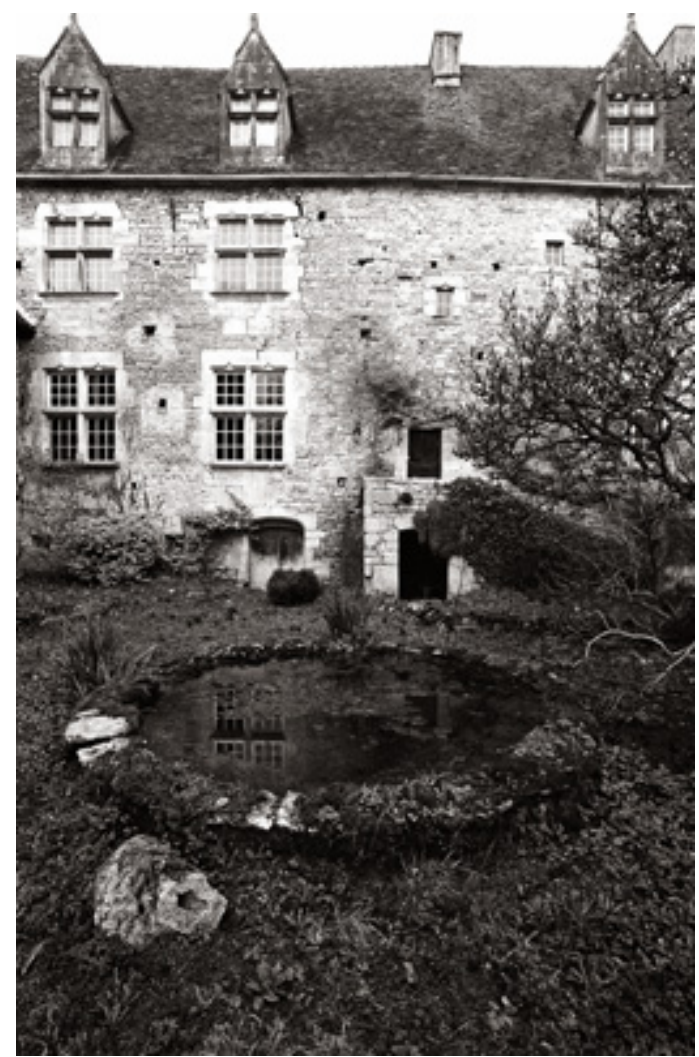

Photo 5: Vierre Garden Pond

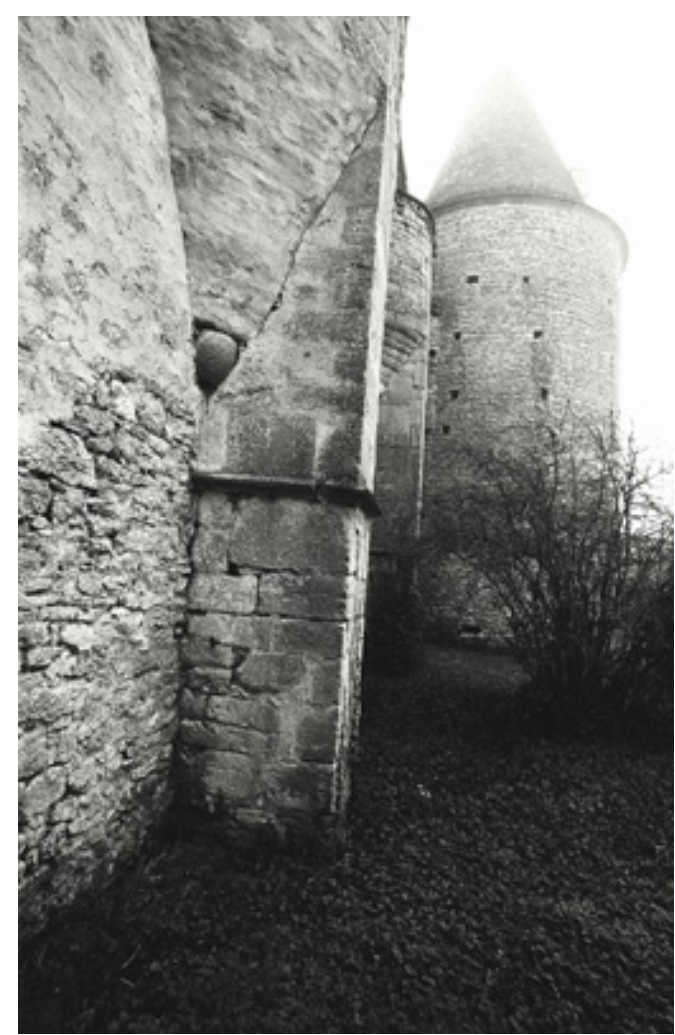

Photo 6: Vierre Turret

\section{Chateau de Beynac}

Chateau de Beynac is a large twelfth century castle in the Dordogne region, once the home of Richard the Lionheart. All of the castles mentioned in this essay are in the old region of Acquitaine, home of the fabled Eleanor (1122-1204), daughter of the Duke of Acquitaine, future Queen of England, and poet of courtly culture (Heer, 1962). Biographies are a good historical resource and on Eleanor there are many, a classic being that of Alison Weir (1999). The noble families that inhabited the medieval castles of France provided land for abbeys, and also frequently provided a son or daughter to join an order as monk or nun, Bernard of Clairvaux being an example. So the ties between abbey and castle were strong, socially, culturally and also architecturally, as the styles and methods of building show. In March 2004, I remember looking through a small leaded window out onto a closed courtyard while climbing a narrow stone staircase in the keep. The scene was redolent with antiquity and I took a photograph looking through the uneven glass. 


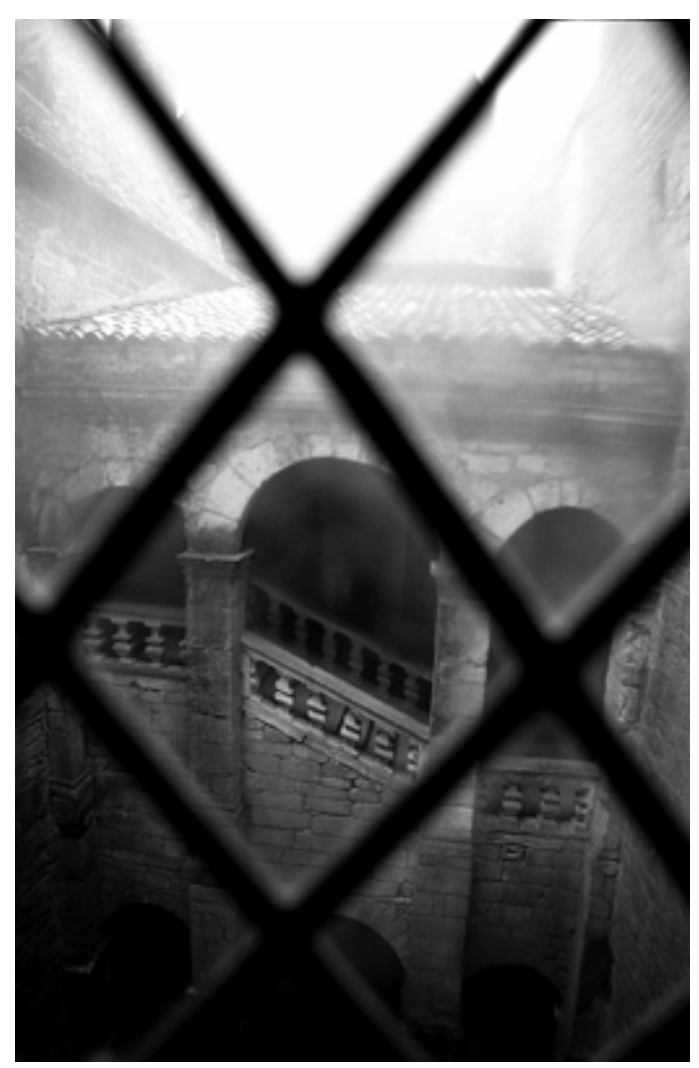

Photo 7: Beynac Courtyard

\section{Abbaye de Fontenay}

I visited Fontenay, a Romanesque Cistercian abbey founded in 1118 by Bernard of Clairvaux, later St. Bernard, in Burgundy, in March 2005. Construction of the abbey church began in 1139 and was completed less than ten years later. The abbey, like many Cistercian abbeys, is situated in a wooded valley with ample water, in this case, a marsh with many springs. Fontenay probably took its name from the latin fontenatum, meaning "afloat upon springs," argues Aynard (no date, p.18). Fontenay is structurally very well preserved. The Cistercians were an order of monks and nuns who broke away from the Benedictine order wanting a more strict application of the Rule of St. Benedict. Benedict, a sixth century Italian monk, wrote an early monks' charter around the precepts of poverty, solitude, love, and contemplation. The breakaway monks built an abbey at Citeaux (Cistercium in Latin) in Burgundy in 1098 then many others followed across Europe (Kinder, 2002).

The Rule specifies the order of daily prayers, sacred reading (lectio divina), the requirements of daily labor, permitted dress (two raw wool habits and cowls without undergarments), and diet-mostly simple vegetarian meals with a little wine. Monasteries provided few comforts such as heat or privacy. The purpose of the order was to contemplate God's work (opus der) and improve one's soul. Hence the decision by the Cistercians to build away from towns in hidden valleys that also provided security (Kinder 2002). Bernard took the mission of the order very seriously and built Fontenay in strict accordance with the Rule that was simple and harmonious in layout and structure, and free from distracting decoration, except for plain leaf designs on capitals (Kinder, 2002). 
The form and construction of a Cistercian abbey was intended to heighten the spiritual dimension rather than engagement with the world. As Kinder notes, a Cistercian church building

was not intended to take one's breath away; quite the contrary, it was intended to bring back the breath, slowly and evenly, to an internal quietude just as the valley site itself invited this slow process of interiorization....The 'message' of the church was one of simplicity, of harmony, of tranquility (p.143).

The point about interiorization is important for the viewer. In order to progress beyond surface appearances, it is necessary to understand the philosophy of the order, be intimately familiar with the buildings and landscape, the effects of weather, etc. and to adopt a patient, receptive, and respectful approach, letting meaning and expression filter into consciousness. As Kinder observes, "something of the original message can still be felt or heard if we pause quietly to look and listen, for the sources that inspired these works spring from a deep human current and a profound human need" (p.26).

The church at Fontenay is built on a modest scale in the shape of a cross with a pointed barrel vault ceiling, a nave with two side aisles pierced by eight small round arched windows per side which let in limited light. The cloister, as was common, is placed on the south wall of the nave. Here it receives the light and warmth of the sun. Also, as was common, the chapter house is situated off the east cloister, the refectory off the south cloister. Other buildings include among others, the infirmary, the monks' dormitory, the cellar, and the kitchen.

In France, in 1789, church properties were seized and sold off by the state, effectively ending centuries of monastic life (Bely, 2001). Fortunately, however, Fontenay has survived almost intact for nine hundred years, a testament to the quality of the building design, materials, and craftsmanship, and most probably, luck. I would like to add that besides abbeys and castles there are many small, village Romanesque churches that reward attention, as shown below.

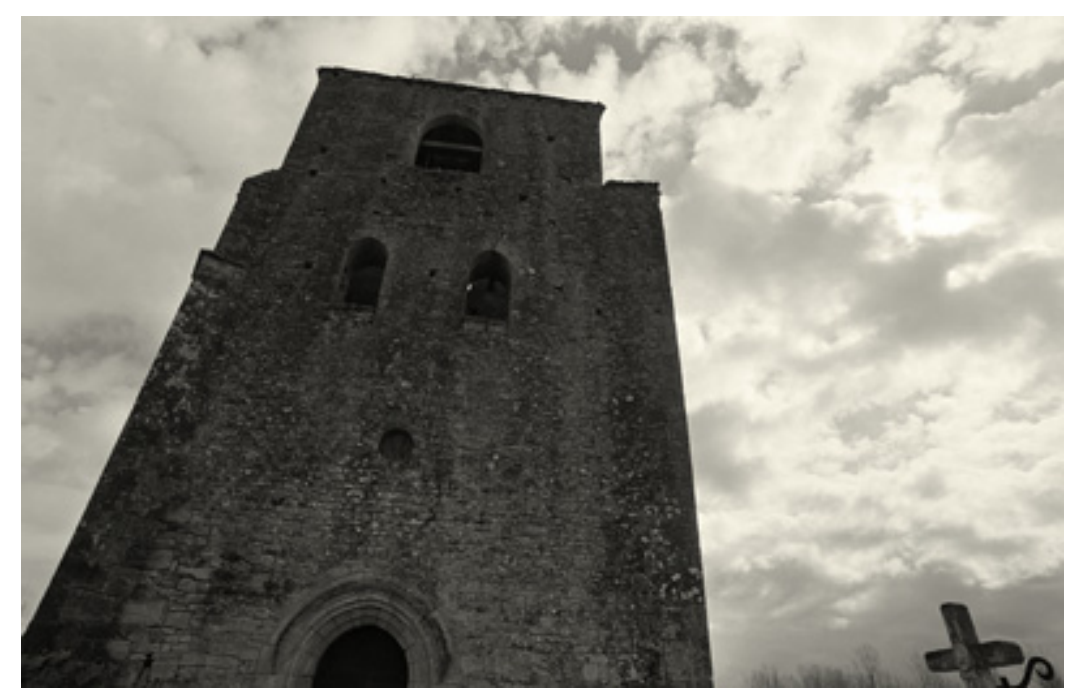

Photo 8: Country Church Tower 
I arrived at the abbey in great anticipation on a cold spring morning in sunshine. Entering the nave I looked up and around, my eyes adjusting to the darkness, as I moved slowly towards the choir. Within a few minutes I was shivering, experiencing a deep and penetrating damp cold. I went back to the car for an overcoat. This conveyed to me the meaning of "stone cold." I visited the open dormitory with its original wood truss ceiling, the fourteenth century sculpture of the Virgin Mary, and then moved through a door in the south aisle of the nave into the cloister illuminated by a low weak sun. I wandered through the cloisters taking in their quadrilateral form, rhythm of round open arches and pillars, low vaulted ceilings, old wooden doors, the effects of light, shadow and patina on stone, and bolts of light projecting through the open exterior arches of the north cloister, until reaching the south cloister. Here I came across an original twelfth century floor, made with stone flagstones extensively worn and modulated by the passage of many feet. I was moved by its beauty and remained in the vicinity for a long while.

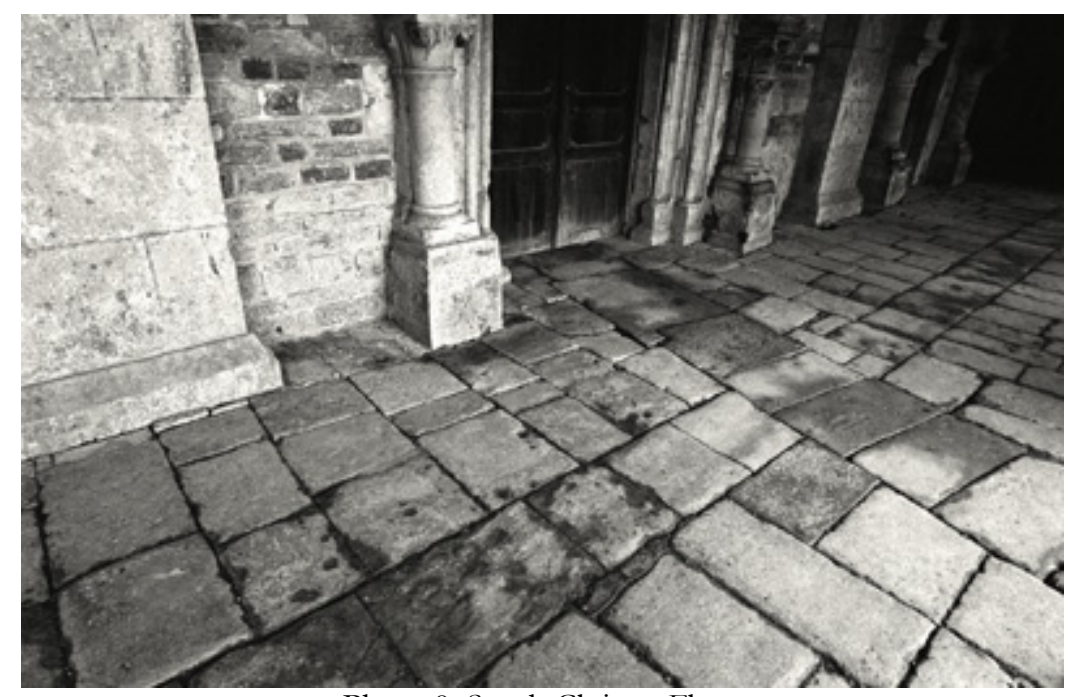

Photo 9: South Cloister Floor

For the rest of the visit I explored the abbey and grounds, walking through the trees, lingering by the stone watercourse. The Cistercians were experts in water systems. I left, chilled throughout, without taking any pictures. I tried to imagine the monks coping with the cold and illness, and realized that through the body I could manage some fellow feeling with the early monks and lay brothers. As they went about their duties, they would be seeing things at a similar speed and orientation to me, although I would be taller, taking in many cues of light, sound, smell, and temperature. The buildings would have seemed large to the medieval eye and the use of stone exotic and expensive, as most buildings were of wood. Notches can still be seen in rising levels in many abbey and castle walls where beams were inserted to support platforms for the stonemasons. I try to imagine the cutting and moving of the stone blocks on site with mallets and chisels and hand-powered winches. During two further visits I took photographs. 


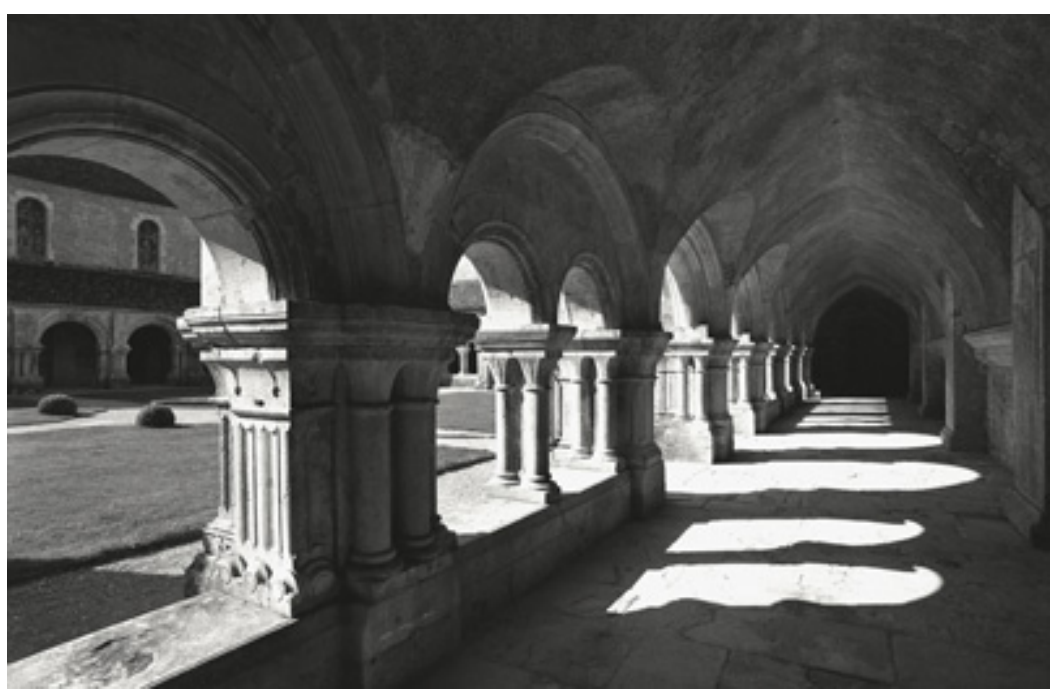

Photo 10: North Cloister

\section{History and Aesthetics}

As I noted earlier, we can conceive of resonance as an understanding, perceptual response to architectural form, but also in my interpretation of Wittgenstein, as a "sympathetic vibration" tuned more towards the sensuous and aesthetic than the epistemological. Nevertheless, sympathy requires knowledge. There is no doubt that experience of medieval architecture is greatly enriched by a knowledge of the genesis of the buildings, their social and philosophical origins, design and building information, general knowledge of the period, the local situation, and the ways of life of the people involved. Such knowledge helps the viewer to see the buildings in light of contemporary beliefs, attitudes, and technical possibilities. ${ }^{5}$

The history is interesting in itself. Sometimes the picture is filled out by small details such as the time that could be spent by monks in the warming room in winter, or that monks were tied for life to their monastery. Monks on an outside mission were given underpants, to be given back on return. One can imagine the coarseness on skin of the raw wool habits. One can also imagine the politics involved in who gets chosen for preferred jobs, the pleasures of early planting in spring sunshine, and moments watching beams of light traverse the interior north nave wall during Vespers or late afternoon prayers. Given enough information, I can imagine the contours of castle life and abbey life (McAleavy, 1996). I can imagine the buildings as they were used, and see them as expressive objects with cultural beliefs behind them produced by people having a particular approach to life.

\footnotetext{
5 By "aesthetic" I mean a perceptual response to orderliness in form that is based in feeling, where an artifact is viewed and appreciated for its own sake: clearly a debt to Kant's Critique of Judgement. As mentioned in the text, an aesthetic response to architecture is also guided, somewhat mysteriously, by historical knowledge. After proposing that aesthetic judgment of beauty is non-conceptual, Kant came to recognize the role of concepts in art while still arguing that they are insufficient for either creation or appreciation (see Kant, 1982, para. 46, 47, 48). In no case can a rule be found that balances and integrates historical knowledge with the sensuous and affective dimension of the aesthetic. This may be a situation where what is difficult to explain theoretically goes more smoothly in practice. For me, the historical element increases aesthetic pleasure.
} 
Through historical research, and literature, some indication can be given of the flavor of life in its lived aspects. A novel such as The Name of the Rose by Umberto Eco (1984) is an example. But a genuine feel for the medieval life is not easy to acquire. As Gier (1981) reminds us in his cultural interpretation of Wittgenstein's famous phrase, "forms of life," "Praying and being certain are phenomena found among all religious peoples. It is therefore general cultural styles that differentiate among various peoples, not the specific life forms" (Gier, p.27). A cultural style, I would assume, is something akin to a way of being, or sensibility. Rather than being conceptual, it is the responsiveness, or manner in which concepts, language, arts, architecture, and human interactions are interpreted and negotiated. Part of this sensibility would stem from the temperament of the individual, though that too must be influenced by experience to some extent.

Crucially, however, as can be seen from the above, as well as contextual knowledge, a sensibility lies behind aesthetic resonance and such is acquired, one might argue, in large measure, by living in a community, something that is clearly not possible in medieval terms for the contemporary student. You have to be there to really "get it," to get the unspoken cues, bodily gestures, the reading between the lines, nuances and inflections, feeling for the appropriate use of words, values, l'art de vivre, and much else. At a distance, and in our own way, we must learn through the architecture available, the histories, and the literature what it means to respond to things in ways that respect the historical reality. As humans we have a shared bodily reality, we can engage physically with the remains of the age, and we can imagine sympathetically what it would mean to be alive in those times, bearing in mind that this capacity derives at least in part from our own humanity. By this I mean such common human propensities as forming communities, living according to beliefs and ideals, having a sense of beauty, learning and building, loving, and sometimes having jealousies.

For me, the key to getting in touch with or developing a feel for the architecture, as I hope I managed to portray in the earlier examples, is to roam around, spending time inhabiting the architecture, acquiring a rich and intimate knowledge of structure, space, details, light and shadow, materials, marks of time, and patinas, but without forcing or planning, allowing one's own senses and feelings to be moved by experience. As Georges Duby notes in an example, "To grasp Fontenay in what makes for its meaning and the force of its beauty, one must approach it step by step, by its forested paths, in October rain, through its brambles and ruts" (cited in Aynard, p.2). This is, for me, what makes the whole experience worthwhile. Exploration leads to discovery and responses in oneself that could not have been known beforehand. This is what is meant, I think, by "knowledge by acquaintance" to use Russell's term (1982, p.24). It is immediate, not theoretical. It is felt, not reasoned. It is unpredictable, not verifiable. In a strange way, such intuitive knowledge is found. I'm using "intuitive" here to mean knowledge of the particular and unique. But it can take time for sympathy and responsiveness to find a way in, time to loosen current attachments and preoccupations, time to get to know and love a place. But there is no escaping the fact that nothing can be known for certain because a resonant response requires the context and validation of an original community, and because our access to history is inevitably shaped by our own contemporary outlook and sensibility. I can only make a best judgment, aided by historical research, regarding how architecture would be seen by medieval persons, and this would vary depending on position and social status.

Consequently it is possible to spend years attending to one building and its surrounding landscape. I have, for example, visited the twelfth century Fountains Abbey in Yorkshire many times over the years and still have not come away with a satisfying feeling of place. Neither have I made a single acceptable photograph. But realistically, I can only adapt myself to the time available and try again. Medieval buildings, particularly Romanesque, have an organic, rustic, country character. They have a meaning and appeal for me unmatched by the later embellishments of the gothic. Perhaps it is the directness of their handmade look, their austerity, and the closeness it is possible to feel to the makers and inhabitants that continues to hold my affections. There is always more to learn and discover. 


\section{Taking Photographs}

Photography gives my medieval interests a direction and purpose. I plot my visits carefully, always allowing for chance discoveries. Photographically I travel light. My preferred camera is a small rangefinder model. It feels compact, solid, balanced, and has a very smooth shutter, ideal for hand-held work. I use only prime lenses, in particular the wide angle $21 \mathrm{~mm}$. These lenses have good resolving power and light gathering qualities. One immediate aesthetic choice is to use black and white film. I find that it moulds the qualities of stone with good tonal and textural range and gradation without the distraction or diffusion of color. I scan the negatives into Photoshop, process minimally, and print on good paper using a high quality photo printer. While such are my choices, they are not essential. Others may prefer to make a different set of arrangements.

I do not take many pictures, as a camera can be a distraction from engaging with the architecture. In a way, for me, a photograph is a trace of an experience, rather than an object pursued as a definite goal. I do not plan to take specific photographs. Also, following Cartier-Bresson, I favour the single-stroke approach (Montier, 1996), which means, in analogy with Chinese ink and brush calligraphy, you take the photograph and then preserve its from-the-moment integrity, trusting the eye's judgment at the time, avoiding cropping or aggressive manipulation afterwards that can alter the energy and character of the picture. Getting a single photograph that works (and I will try to explain what this means) is a rarity. Importantly, the self and its ego must be eased back, otherwise the rational, goal-driven will takes over and problems arise, such as determining in advance a list of pictures. Only by gradually tuning out the self through gentle and prolonged attention to the surroundings can I get to a place of flow, to let loose the bowstring without thinking, as Herrigel (1989) would have it. Only by forgetting the camera, making adjustments to aperture or shutter speed unconsciously, can there be any hope of a resonant connection.

The term "making" is more appropriate than "taking" in relation to photography, as the photograph emerges from an amalgam of personal awareness, imaginative sympathy for, if not immersion in subject, technical fluency, and aesthetic perception. Images are not there for the taking, as it should be remembered that the photographer plays a necessary formative role in shaping impressions into a satisfactory pattern or composition. Also, problematically, the eye in our image-laden world is already schooled in a way of seeing pervasive in our culture. We are trained to channel surf, to see as the video camera sees, to move on quickly from scene to scene, usually at eye level. Whereas the challenge in photographing ancient material is in slowing down and, without forcing, letting the eye play freely over the forms and stones, moving in close, stepping back, raising and lowering eye level and angle, as the situation requires. A single photograph that has a fresh, individual quality of reality is a marvel, but I am getting ahead of myself.

What tends to happen for me is that in a single arresting moment, some portion or fragment in the field of view stands out as aesthetically compelling. The senses are alive, tingling with feeling that I can only say is akin to love. I am moved by the beauty. I have a strong sense of things coming together into a satisfying whole, that the image in the viewfinder will work as a picture. Is this an aesthetic experience?

Wittgenstein's idea of resonance seems true to my experience. On rare fortunate moments, perhaps given by luck, mood, receptiveness, personal preparedness, and quality of light, a sympathetic vibration or harmony between the subject and me obtains. I am in the moment. I think I understand, qualitatively, what the architecture is saying but in practice, with aesthetics, you have to trust your own responses. Maybe the photographs can show more of what I cannot put into words.

Later, back home, I look through the contact sheets hoping to find pictures that will confirm my original intuitions. If I am lucky, I will find an image in the loupe with some sparkle in tone, individuality, and expression of a certain medieval sensibility. I will feel moved again as by the original experience. The picture is then, for me, an aide de memoire. 
Photographing the medieval is a special interest for me. In many local environments, however, it is possible to find architecture, both grand and simple, that can inspire aesthetic and historical interest. In Vancouver, for example, there are many old buildings that are deemed Heritage sites. This is usually marked by a small plaque giving the individual history of a building. Also in many neighborhoods it is possible to find houses, hotels, small shops, churches, offices, and apartment buildings that are worthy of exploration through photography and other arts media. Such artistic work can reveal the richness and distinctiveness of the local cultural community and is a worthy educational activity. ${ }^{6}$

\section{References}

Aynard, F. (no date). Fontenay: The abbey and the vale. (L. Ash, Trans). Les Editions du Huitieme Jour. Bely, L. (2001). History of France. (A. Moyon, Trans.). Paris: Editions Jean-Paul Gisserot. Eco, U. (1984). The name of the rose. (W. Weaver, Trans.). New York: Harcourt Inc. Gier, N. (1981). Wittgenstein and phenomenology. Albany: State University of New York Press. Heer, F. (1962). The medieval world: Europe 1100-1350. (J. Sondheimer, Trans.). New York: Mentor. Herrigel, E. (1989). Zen in the art of archery. (R.F.C. Hull, Trans.). New York: Vintage Books. Kant, I. (1982). The critique of judgement. (J.C. Meredith, Trans.). Oxford: Clarendon Press.

Kinder, T. N. (2002). Cistercian Europe: Architecture of contemplation. Grand Rapids Michigan: Wm. Erdmans Publishing Co. \& Kalamazoo, Michigan: Cistercian Publications.

Kluckert E. (1997). Romanesque building styles. In R. Toman (Ed.), Romanesque: Architecture, sculpture, painting, (F. Hulse \& I. MacMillan, Trans.; pp. 20-31). Cologne: Koneman.

McAleavy, T. (1996). Life in a medieval abbey. London: English Heritage.

Montier, J.P. (1996). Henri -Cartier-Bresson and the artless art. (R. Taylor, Trans.). London: Thames and Hudson.

Perloff. M (2004). But isn't the same at least the same? In J. Gibson \& W. Huemer (Eds.), The literary Wittgenstein (pp. 34-47). New York: Routledge.

Russell, B. (1982). The problems of philosophy. Oxford: Oxford University Press.

Weir, A. (1999). Eleanor of Aquitaine. New York: Ballantine Books.

Wittgenstein, L. (1980). Culture and value. (G.H. Von Wright \& N. Hyman.; Eds.; P. Winch, Trans.). Chicago: University of Chicago Press.

Wittgenstein, L. (1974). Philosophical investigations. (G.E.M. Anscombe, Trans.). Oxford: Basil Blackwell.

\section{About the Author}

Stuart Richmond is a professor of arts education at Simon Fraser University. He can be reached at stuart_richmond@sfu.ca

\footnotetext{
${ }^{6}$ The purpose of this essay is to provide an account of what it means to experience medieval architecture with resonant understanding. While I would argue that the narratives and explanations have veracity, I have not developed conditions for the attainment of such understanding given the possible indeterminacies of aesthetics and history and the variability of human response. Wittgenstein (1974, para. 88) reminds us that circumstances and purpose determine what standard of exactness is appropriate.
} 